\title{
Tradition, Innovation, and Experimentation: The Dramatic Stage and New Modes of Performance in Late Eighteenth-Century Naples
}

\section{Anthony R. DelDonna}

Summary: Naples in the last thirty years of the eighteenth-century was characterized by a fervent climate of theatrical experimentation. Although too often viewed as the last stronghold of Metastasian dramatic principles and traditions, the city was deeply influenced by the "reform culture" of Northern Europe. These exterior influences were bolstered by the contributions of local practitioners, whether composers, performers, and theorists. This essay is a brief consideration of how the ideas of "reform culture" affected contemporary Neapolitan theatrical practices and the emergence of new works in the city. A critical source for "reformed" theatrical philosophy was the work of Antonio Planelli (1747-1803), whose treatise Dell'opera in musica (1772) is a significant exploration and commentary on the dramatic stage of the Bourbon capital. Progressing from theatrical philosophy to existing practice, I will consider how the prevailing conditions animated the creation of the largely unknown cantata/ pastorale/opera, La pietà d'amore (1782) by the singer, composer, and Calzabigi protégé Vito Giuseppe Millico (1737-1802), created expressly for Naples under the sway of reform principles and his direct collaborations with the poet of Orfeo, Alceste, and Paride ed Elena. My study concludes with an examination of the emergence of the so-called "Lenten tragedy" or azione sacra per musica, a theatrical form created in the exclusive environs of the Teatro di San Carlo, the royal theater of the Bourbon capital, yet imparting a new theatrical aesthetic and modes of representation for contemporary sacred genres consistent to select ideals of reform culture.

Naples in the last thirty years of the eighteenth-century was characterized by a fervent climate of theatrical experimentation within both traditional venues (above all the Teatro di San Carlo) and those private (such as performances sponsored by 
the Nobile Accademia di Musica delle Signore Dame e de' Signori Cavalieri). ${ }^{1}$ Although long viewed as among the last strongholds of heavily stereotyped Metastasian dramatic principles and traditions, the city was attuned to the tenets of "reform culture" emanating from Northern Europe, whether Vienna (through the presence of no less than Raniero de' Calzabigi in Naples) or the Germanic States, not to exclude the contributions of local practitioners, including composers, performers, and theorists. My essay is a brief consideration about the introduction of the ideas of "reform culture" on contemporary Neapolitan theatrical practices and how it impacted the emergence and specific conceptualization of new works created in Naples. A critical source for the emergence of a "reformed" theatrical philosophy was the work of Antonio Planelli (1747-1803), whose treatise Dell'opera in musica (1772) is among the most significant explorations of and commentaries on the contemporary dramatic stage of the Bourbon capital. ${ }^{2}$ Progressing from theatrical philosophy to existing practice, I will consider how the prevailing conditions animated the creation of the largely unknown cantata/ pastorale/opera, La pietà d'amore (1782) by the singer, composer, and Calzabigi protégé Vito Giuseppe Millico (1737-1802), created expressly for Naples under the sway of reform principles and his direct collaborations with the poet of Orfeo, Alceste, and Paride ed Elena. ${ }^{3}$ My study concludes with an examination of the emergence of the so-called "Lenten tragedy" or azione sacra per musica, a theatrical form created in the exclusive environs of the Teatro di San Carlo, the royal theater of the Bourbon capital, yet imparting a new theatrical aesthetic and modes of representation for contemporary sacred genres consistent to select ideals of reform culture.

\footnotetext{
${ }^{1}$ The scholarship on the eighteenth-century theatrical culture of Naples is vast, in brief see Cotticelli and Maione 2009; Mattei 2009; Robinson 1972; Cotticelli and Maione 1996; Croce 1891; Mancini 1987; Imbruglia; DelDonna, 2012. For information on the Nobile Accademia, see Tufano 2011.

${ }^{2}$ Planelli 1772; see also the modern edition with critical commentary, Dell'opera in musica (ed. Francesco Degrada 1981). All subsequent references in the critical notes will be to the modern edition.

${ }^{3}$ For the most authoritative work on Calzabigi in Naples, see Lucio Tufano 2012; Tufano 2005; Tufano 2006; "Il poeta 'cadente' e il Re 'filosofo.' Versi ignorati di Ranieri Calzabigi ...;" Marri and Russo; Marri; Bellina; Candiani.
} 


\section{Planelli, Dell'opera in musica (1772)}

The establishment of the Teatro di San Carlo in 1737 and its near exclusive cultivation and performance of Metastasio's dramas endured for the better part of the eighteenth century. Beginning at mid-century, there were increasing demands for renewal, change, and ultimately reform. ${ }^{4}$ To these growing appeals for theatrical transformation, Antonio Planelli added his considerable insights in the form of the treatise Dell'opera in musica (1772). This tome represented the first systematic analysis of the Neapolitan dramatic stage, interpreting and critiquing through a rigorous methodology the constituent elements of tragedy. Planelli's individual delineation and definition of tragedy as comprised of poetry, music, interpretation, scenography and dance offered the basis for a cumulative assessment of contemporary performance practices in Naples. The philosophical and practical orientations of Planelli's analyses were grounded in the works of his native city, yet they were transparently animated by the innovations in evidence in Gluck and Calzabigi's Orfeo and Alceste. ${ }^{5}$ These compositions serve not simply as models of conception and construction, but also it is the declarative preface to Alceste and its aesthetic creeds that are channeled throughout the discourse of Dell'opera in musica. ${ }^{6}$ Gluck and Calzabigi's exhortations "to restrict music to its true office of serving poetry" and create a libretto marked by "heartfelt language, strong passions, interesting situations, and endlessly varied spectacle" are the broad-based philosophical and practical framework for Planelli. ${ }^{7}$ Echoing the

\footnotetext{
${ }^{4}$ A particularly famous example of these calls was by Count Danza, who claimed "Il pubblico è stufo ormai di veder sempre rappresentate le opere di Metastasio, le quali [...] han perduto in buona parte quel diletto che assolutamente dalla novità il pubblico riceve [...]. Ha perciò creduto la Giunta, per eccitare la curiosità del pubblico, fosse a proposito il mettere in iscena qualche opera nuova. (The public is fed up by now of always seeing staged the operas of Metastasio, which have lost in large measure that pleasure that the public receives entirely from new works ... The Giunta therefore believes, in order to interest the curiosity of the public, it could be proposed to stage several new works.) As quoted in Mattei, "La scena napoletana e il contesto europeo," 94.

${ }^{5}$ See Tufano, "La riforma a Napoli," 103-120.

${ }^{6}$ Tufano asserts that Planelli owned the printed score to Alceste (1769), which contains the address by Gluck. See Tufano, "La riforma a Napoli," 121-122. For a contemporary translation in English, see Weiss, and Taruskin 2008, 254-255.
}

${ }^{7}$ Ibidem, 254-255. 
declarations of his Viennese predecessors, Planelli's point of departure is a careful presentation and rendering of the "qualities that comprise the perfection of stage drama." "The foundation in his view (and consistent to his source of inspiration) remains the poetic basis of an opera to which all other elements are destined "to assist and to strengthen." Whereas the terse brevity of Alceste's dedication was limited in specificity and detail (by design), Planelli embarks on an extended investigation of the norms and abuses associated with tragedy, beginning with the composition and performance of recitative and aria.

The critical aim of all stage drama, Planelli declares, is toward the outcome of expression. He therefore posits a series of "rules" appropriate to theatrical music that should govern recitative and aria, which ultimately underline connections to his models. Working from the maxim that "theatrical music demands a style with fewer notes," ${ }^{10}$ Planelli chides the excessive use of melodic embellishment, the extreme extension of the vocal compass and the obliteration of the poetic content through excessive melismas. The aim of the poet and composer should be the perfection of a style appropriate to each sentiment. These "rules" become the basis for critical assessment of and how to approach the creation of recitative (whether the secco or accompanied styles) and aria for the stage. The scope and methodology of the discourse far exceeds that of Alceste, yet Planelli concludes this section by citing in full the dedication to that opera, in order to underline the continuity, not to mention currency of his treatise to the reform movement. ${ }^{11}$ Planelli humbly concedes as an introduction to the lengthy citation of Alceste, that "while in this extreme part of Europe I outline only a theoretical essay, albeit partial and brief, of that music, in another part [of the continent], a worthy professor demonstrates its practice so exquisitely." ${ }^{12}$ The presentation of this characteristic topos of reform does not end with the conclusion of this section in Dell'opera in musica as the author will return often to the theme to underline cumulative points. Rather Planelli

\footnotetext{
${ }^{8}$ Planelli, Dell'opera in musica, 14.

${ }^{9}$ Planelli, Dell'opera in musica, 15 . Soccorrerela e sostenerla.

${ }^{10}$ Planelli, Dell'opera in musica, 67: "Lo stile della musica teatrale vuol poche note."

${ }^{11}$ See Planelli, Dell'opera in musica, 79-80.

${ }^{12}$ Planelli, Dell'opera in musica, 79. "Che mentre in questa estrema parte d'Europa io stendea un teorico saggio, ma debolissimo e breve, di quella musica, in altra parte un degno professore ne mostrava sì sensatamente la practica."
} 
Tradition, Innovation, and Experimentation: The Dramatic Stage and

New Modes of Performance in Late Eighteenth-Century Naples

momentarily sets aside this thread to address the other constituent elements of theatrical music, albeit at times traversing well-worn paths.

The most compelling elements of his continuing discussion, nevertheless, which resonate deeply with the progressive climate of theatrical reform in Europe and Naples, are centered on the element of pronunziazione within contemporary drama. For Planelli, pronunziazione was the cumulative act of "interpretation" and rested upon the critical concept of gesto. The notion of gesto to Planelli posited a broad understanding, embodying such foundational ideas as action, comportment, and representation. Yet gesto is not simply relegated to physical movements, which Planelli cited as encompassing the entire body, enacted in service of expression. Rather it rested on a calculated philosophical orientation and specific methodology to be imparted to performers in order to bring to fruition the realism and expression of tragedy. Delving more deeply into the concept, Planelli identifies three species of gesto: imitativo (or imitative), indicativo (or explanatory and/or suggestive) and affettivo (or emotional). The idea of the imitativo is not to be confused with mimesis, but rather an action that spurs a physical response to complete characterization. In a correlative manner, the gesto indicativo is inherently explanatory, reinforcing meaning, leading the audience to understanding. It is in the gesto affettivo that an action conveys emotion, although Planelli is quick to note that all three species can impart sentiment. To Planelli, the affettivo species was paramount because it required a complete physical commitment by the performer. As is often the case in the treatise, the author nevertheless tempers his endorsement, cautioning against excess and urging a judicious sobriety and discernment in realization. Intimately related to the concept of pronunziazione, Planelli delves into an area which he simply references as voce. This subtle shift maintains the theme of interpretation, yet guides the discourse, once again, toward the singer, modes of representation and of course discussion of the aria. Nevertheless, Planelli urges several fundamental principles that all vocalists must adhere to; 1) Fluency in the language of the drama; 2) Precise declamation (as if the soloist were speaking); 3) All exaggeration of the poetry must be avoided such that the audience can discern the rhyme and even meter; and finally 4) The singer must shape the voice and singing in service of affect (Planelli 88-89). These criteria and transparent references to contemporary abuses by the primi divi of the stage, serve as the basis for Planelli's broad denunciation of the castrato voice. Continuing this theme, while demonstrating a notable awareness of prevailing tastes, whether social or artistic, he advocates in strong language for engagement 
of the tenor voice, citing several of the premiere contemporary practitioners. In perhaps the most strident moment, Planelli resorts to objections to the castrato voice on the basis of ethical morays, decrying the damage to society caused by the evirazione of young men. The social moralizing is; however, cast aside for Planelli to enumerate in conclusion the specific techniques to acquire successful pronunziazione. Just as scholars engage in a thorough study of history and rhetoric, so too must the "actor" master these disciplines and even contemplate the representative arts of painting and sculpture. It is only through the complete training and embodiment of the role that a successful interpretation can be rendered on the theatrical stage.

Planelli's treatise, of which select passages have been heretofore cited, posits the image of a local theatrical culture fully engaged with new and emergent ideas about contemporary performance practice with a specific emphasis on reform initiatives. His specific advocacy for the innovations and works of Gluck and Calzabigi were not his alone and as the decade unfolded, there was an increasing interest in the staging of Orfeo, Alceste, and Paride ed Elena in Naples. Two years after the issue of Planelli's ground-breaking study, Orfeo was staged twice in 1774, albeit in quite different renderings in public and private. ${ }^{13}$ The Nobile Accademia di Musica initiated its private soirees with performances of Paride ed Elena (1777 and 1779, twice in the latter year) and a subsequent performance of Alceste (1779), which was also staged at the Teatro del Fondo (1785). ${ }^{14}$ In the midst of this intense cultivation of reform works, Calzabigi himself returned to Naples embarking on the final stage of his illustrious career. His arrival was commented upon in private correspondence from no less than Pietro Metastasio to Saverio Mattei (a scholar of antiquity, librettist and amateur musician), who noted, "It is known here [Vienna] that Calzabigi abandons Tuscany to come breathe the salubrious and smiling auras

\footnotetext{
${ }^{13}$ As detailed by Tufano, Orfeo was initially programmed in the private theater of the Bourbon court in the Royal Palace (based on the version staged in Parma in 1769) and thereafter in the Teatro di San Carlo. For the latter, Johann Christian Bach was engaged to expand the length of the opera by composing additional music. Tufano attributes the intense interest in the dramas of Gluck and Calzabigi in part to Ferdinando IV and Maria Carolina, who were well acquainted with these compositions. There is also evidence of further performances in the Royal Palace of Caserta, outside of Naples. See Tufano, "La riforma a Napoli," 107-111; also Robinson 1972-73, 233-413.

${ }^{14}$ Calzabigi was directly involved with the staging of Alceste at the Fondo, which also hosted a performance of his pasticcio, Cook o sia Gli inglesi in Othaiti. See M.I. Maffei, "Alcune osservazioni su Cook o sia gl'Inglesi in Othaiti," 209-225.
} 
Tradition, Innovation, and Experimentation: The Dramatic Stage and New Modes of Performance in Late Eighteenth-Century Naples

of the beautiful Partenope." 15 The engagement and impact of Calzabigi with the theatrical culture of Naples has been well-documented by other scholars, above all Lucio Tufano; however, an entirely neglected aspect of such research is the contributions of the poet's local collaborators to the burgeoning number of reform compositions. Calzabigi worked at length and in close partnership with the castrato and composer Giuseppe Millico. In particular, Millico's dramatic work La pietà d'amore (1782) was created, albeit with the poet Antonio Lucchesi, as a transparent channeling of the ideals of Calzabigi's works, representing a further deepening of the burgeoning theatrical reform in the capital city.

A native of Terlizzi in Apulia, Millico was educated in the Neapolitan conservatory system before embarking on a far-ranging career as a castrato. ${ }^{16}$ He spent the period of 1758-65 in St. Petersburg, earning the moniker "il Moscovita," before beginning a highly productive collaboration with Gluck and Calzabigi at the end of the 1760s. Millico sang the role of Orfeo throughout Europe and he created the role of Paride in Paride ed Elena in Vienna in 1770. By 1775, Millico had returned to the Italian peninsula (performing widely) and in 1780, he was engaged in Naples as "Musico Soprano della Real Cappella." Millico moved in rarified social and political circles in Naples, reestablishing his collaborative relationship with Calzabigi. This time Millico was enlisted; however, as composer not as virtuoso performer. Indeed Calzabigi commissioned Millico to set his Les Danaïdes and Ipermestra for private and public representations in Naples. The poet avowed, in speaking of this relationship, that he had declaimed the libretto aloud to Millico, so that all of the textual nuances could be then incorporated into the musical setting. This manner of partnership moved Calzabigi to declare ultimately that Millico was "no less a celebrated singer than a superb composer." ${ }^{17}$ These intimate and ongoing interactions undoubtedly influenced and animated the creation of Millico's La pietà d'amore.

\footnotetext{
${ }^{15}$ Pietro Metastasio, Tutte le opere di Pietro Metastasio, vol. 5, footnote 2473, p. 596: "Si sa qui che il Calzabigi abbandona la Toscana per venire a respirar le salubri e ridenti aure della bella Partenope."

${ }^{16}$ Croll and Brandenburg. "Millico, Giuseppe." Grove Music Online. Oxford Music Online. Oxford University Press, accessed February 19, 2015, http://www.oxfordmusiconline.com/ subscriber/article/grove/music/18697; Finscher, 1975; Martina; Burney, II, 263-265; Di Benedetto 2000.

${ }^{17}$ As quoted in Bellina (ed.), Ranieri Calzabigi..., Tome 1, 259. Non moins célèbre chanteur qu'excellent compsoiteur.
} 
In the manner of Alceste, the published score (a rarity in eighteenth-century Naples) of La pieta d'amore is preceded by a lengthy declaration of aesthetic principles addressed to the poet Antonio Lucchesi ${ }^{18}$ and the general audience. ${ }^{19}$ The specific content and tone are meticulous appropriations of Calzabigi's aesthetics and bear evident resemblances as well to the philosophies espoused by Planelli in Dell'opera in musica. After a laudatory acknowledgement of Lucchesi, Millico delineates his theatrical aesthetics, noting

In the sinfonia, I believe that the program of the opera must be given, as I am of the opinion that this will be imperatively useful for the unity of the entire work. In the progress [of the music] I have attempted to express with great simplicity the texts, adapting them to those instruments, which I have judged as suitable to the highest expression; to that end I have determined to omit that common, perpetual monotony that has revolted us for much too long. Observant critics, nevertheless, will find that my music is not cleansed of those errors, which have been condemned by true good taste, and they will also note some subtle ornamentation and the repetition of words, which has been so sagaciously condemned by Signor Planelli in his tome entitled l'Opera in Musica. ${ }^{20}$

\footnotetext{
${ }^{18}$ Lucchesi (1716-1803) was the sixth Prince of Campofranco; his family line, the LucchesiPalli, was among the most prestigious of the Kingdom, known for their artistic patronage. His brother Giuseppe served as impresario at the Teatro del Fondo in 1785 in which Gluck and Calzabigi's works were featured prominently. The renowned library of the Lucchesi-Palli (circa thirty-thousand volumes including autograph musical manuscripts from the eighteenth century) is now housed in the National Library of Naples. See Borelli, La Lucchesi-Palli.
}

${ }^{19}$ Giuseppe Millico, La pietà d'amore. Dramma messo in musica. (Napoli: Giuseppe-Maria Porchelli, 1782), 1-7. I consulted two copies of the score, the first in Naples at the Biblioteca del Conservatorio San Pietro a Majella (shelfmark U.5.5) and a second copy held in the Georgetown University Special Collections division. I am grateful to Dr. John Buchtel for the acquisition and allowing me repeated access to the manuscript at Georgetown.

20 Millico, La pietà d'amore, Preface 3-4. Nella sinfonia ho creduto di dover fare il Programma dell'opera, sembrandomi, che ciò indispensabilmente convenga all'unione del tutto. Nel progresso ho cercato di esprimere colla maggior semplicità le parole, adattandovi quegl'Istrumenti, che ho giudicati opportuni alla migliore espressione, ho procurato infine di togliere quella commune perpetua monotonia, che cì disgusta da tanto tempo. Mio ciò non ostante $[s i c]$ i critici osservatori troveranno la mia musica non ben purificata da quegli errori, 
Millico's declarations are transparent in their clear debt to Calzabigi and candid reference to Planelli's treatise. His point of departure, noting the function of the overture, is a direct citation from the preface of Alceste. What follows in its wake is not simply an echoing of his creative partner, but more directly a series of succinct paraphrases of Planelli's broad views on the style and usage of recitative, the role of the instrumental accompaniment and perhaps most significantly the composition of the aria and its poetic basis. It is the topic of the aria to which is devoted a wide ranging consideration, including the preferred compositional attributes, qualities, and cumulative style. Millico also delves into the appropriate formation of musicians. Indeed Millico implores both contemporary composers and singers toward "the attainment of true understanding in order to understand the sensitivity of the words and enter into the soul of the poetry." ${ }^{\prime 21}$ To this end and once again a clear appropriation of Planelli, he notes "to arrive at this perfection, it is needed to change the present system of education." ${ }^{22} \mathrm{He}$ specifies the study of music fundamentals, elocution (encompassing diction, pronunciation, and articulation, all alluding to Planelli's concept of pronunziazione), history, and poetry; in sum all that is appropriate to the particular musical craft. Millico reserves his most direct comments on the art of singing itself, imploring ironically the "exercise of the natural voice" and citing specific technical issues that often result in "revolting flaws." ${ }^{23}$ These observations build the foundation for his cumulative judgment that "in my opinion it is necessary, that the maestri of vocalists should be the most famous singers, like those, who through experience, and by example would be able easily to instill these refinements." ${ }^{24}$ Millico presents the example of his own training and career as the evidence for these conclusions. This also guides the discussion once again toward his past collaborative work, this time a recollection

che condannati sono dal vero buon gusto, e vi osserveranno qualche breve gorgheggio, e qualche ripetizione di parole, cosa che saviamante condanna il Sig. Cavaliere Planelli nel suo libro intitolato Opera in Musica.

${ }^{21}$ Millico, La pietà d'amore, 4. All'acquisto della vera cognizione per intendere il sentimento delle parole, ed entrare nello spirito delle poesie.

${ }^{22}$ Millico, La pietà d'amore, 5. Per arrivare però a questa perfezione bisognerebbe cambiare il presente sistema di tutte le scuole.

${ }^{23}$ Millico, La pietà d'amore, 6.

${ }^{24}$ Millico, La pietà d'amore, 6. A mio credere necessario, che i maestri de' cantanti fossero i più famosi cantanti, come quelli, che coll'esperienza, e coll'esempio potrebbero facilmente insinuar loro queste delicatezze." 
of experiences with Gluck. ${ }^{25}$ Although the digression is fleeting, it does offer Millico the occasion to declare in sum: "Therefore art, effort, [and] study are the basis of formation for the singer. The manner of singing is none other than that, which is the ability to stir the passions, and instill them in the heart." ${ }^{26}$ Although the taxonomy of terminology is different from that of Planelli, it is unmistakably evident that Millico's views are rooted in Dell'opera in musica and his own professional experiences. The existence of the score to La pietà d'amore allows the opportunity to scrutinize carefully and juxtapose how Millico placed into practice these philosophical and aesthetic principles.

Lucchesi's drama (which has been variously referenced as a cantata, pastorale, and opera) presents a magical fable at whose core resides the themes of female virtue, fidelity, and redemption. ${ }^{27}$ It centers on Climene, who awakens to the realization that she has been kidnapped and transported to an invisible palace and mythical kingdom, presided over by Orosmane, the "gran Silfo." ${ }^{28}$ Orosmane (who is advised and assisted throughout by Morgana) offers Climene immortality, if she agrees to be his wife and remain for eternity in the fairy-tale paradise. For her part, Climene is grief stricken and tormented, longing only to return to her true love Azem. She and Azem (who is also later abducted and tortured) offer supplications to Cupid, whose "divine intervention" will ensure the lieto fine. Bolstered by choirs of "spirits" and "souls who sing and dance," Lucchesi crafts a rich scenic apparatus to accentuate the principal plot line, which bears an unmistakable resemblance to Calzabigi's Orfeo in its themes of dislocation, amorous intrigue and otherworldly deities.

As Millico freely acknowledges in his declaration, the score does retain traditional elements such as secco-recitative and the da capo and dal segno aria types; the latter are derived from rather stereotypical verse forms. Yet there is also

\footnotetext{
${ }^{25}$ Millico recollects how he demonstrated his pedagogical methods to Gluck through the training of the latter's niece Marianne Gluck. See Millico, La pietà d'amore, 6-7. Also Burney The Present State of Music in Germany, 263-265.

${ }^{26}$ Millico, 7. "Dunque l'arte, la fatica, lo studio può formare il cantante. La maniera di cantare non è che una, cioè la cognizione di muovere le passioni, ed insinuarsi nei cuori."

${ }^{27}$ Antonio Lucchesi, La pietà d'amore. Cantata a cinque voci. (Napoli, 1782). The libretto is located in the Biblioteca del Conservatorio San Pietro a Majella; shelfmark Rari 10.7.11/11 [note] Olim: P.1.18/m.

${ }^{28}$ The "sylphs" were mythological spirits of the air, elemental in their very essence and described by Paracelsus as invisible. See Ball, The Devil's Doctor, 302-307.
} 
a marked incorporation of accompanied recitative, alternative aria schemes and ensembles, whether modest duets or the engagement of choral groups. It is in the second act as the drama works toward its dénouement that Millico comes closest to a full implementation and mastery of reform concepts outlined in his preface and the treatise of Planelli. Act II; Scene 8 presents the critical confrontation between Orosmane and Climene, in which she refuses one last time his entreaties of marriage and must then witness the transformation of the mystical gardens into a grove of Cypresses, where the corpse of Azem now lies. ${ }^{29}$ Millico sets this critical moment as an accompanied recitative scored for the strings to underscore the raw expression of emotion. Orosmane's parsed melodic line, ${ }^{30}$ rises and falls avoiding large intervallic leaps, is set against the aggressive rhythmic accompaniment of the violins that furiously hammer away at the pedal sonorities of Eb-C7-F-Bb. Yet the accompaniment is a measured and meticulously balanced counterpart to Orosmane's disdainful rebuke that completes rather than overshadows the melodic line. Each vocal utterance is; moreover, set off by brief rests, placing a premium on the grammatical construction of the verses.

Climene's response offers a notable escalation in the emotional tension of the scene as she looks upon Azem's lifeless body. Millico underlines the dramatic moment through new accompaniment figures (both melodic and rhythmic) and frequent shifts in tempo, while preserving the declamatory vocal line. A sense of fate prevails over Climene's recitation as it winds toward conclusion and there is a brief, yet powerful caesura to the action. It is in the succeeding ensemble, a chorus of "shadows," that Lucchesi and Millico again evoke the innovative qualities of Calzabigi's Orfeo. The scenic directions note, much in the manner of their model, that the ensemble "dances around the body of Azem and sing." ${ }^{1}$ What unfolds is an active dialogue between the chorus and Climene as soloist. The music takes the shape of a five-part rondo (ABACA), similar to the famed "Che

\footnotetext{
${ }^{29}$ Lucchesi, La pietà d'amore, Act II; Scene 8, 27.

${ }^{30}$ Lucchesi, La pietà d'amore, 26-27. Orosmane: Non affliggerti più. Vedrai fra poco fin dove giunge il mio potere. Avrai quell'Azem, che sospiri. Al mio furore, alla vendetta mia, barbara, ingrata, questo conviene sacrifizio orrendo: Ripigliati il tuo Bene, ecco te'l rendo. (You will not be vexed further. You will see soon/the full extent of my power. You will have/Azem, for whom you long. Only my furor,/my vendetta, uncivilized and ungrateful woman,/Befits this horrendous sacrifice:/Reclaim your beloved, here I return him to you.)

${ }^{31}$ Lucchesi, La pietà d'amore, Act II; Scene 9, 28. Coro d'Ombre che girano intorno al corpo di Azem, e cantano.
} 
farò senza Euridice." The choir is entrusted with a lilting melodic refrain that returns for each successive stanza of ottonari verses of new poetry, promoting an ongoing, active narrative. In contrast, to reflect both the characteristic musical structure and her dissenting view within the dramatic narrative, Climene sings a new melody for each of her poetic verses (B and C). Millico accentuates the contrast between each group not simply through the distinct melodic lines, but also changes in harmony and the instrumental accompaniment figures. As the second act of La pietà d'amore winds toward conclusion, Millico creates a closelyknit series of interlocking musical soliloquies. They unfold as a second chorus of singing and dancing for the shadows, a moving accompanied recitative and brief aria for Cupid with a final ensemble for the principals and choir, the last of which is structured once again as a rondò. The continuity between libretto and musical setting creates a tableaux-like effect promoting a seamless, fluid unfurling of the drama. The opera concludes with the return to life of Azem and his joyous reunion with Climene, achieved through the direct (and divine) intervention of Cupid. Albeit a stereotypical theatrical conclusion, it accentuates the prevailing themes of fidelity and redemption.

Millico's rendering of Lucchesi's fable, nevertheless, is a masterful interpretation of Calzabigi and Gluck's reform initiatives underscored by his own direct collaborations with the poet and composer. The content of La pietà also illustrates a compelling awareness of Planelli's aesthetic theories and Millico's own extensive experience as a primo castrato throughout Europe. These diverse stimuli coalesce to place into action a skillful realization of the opera, which posit a range of interpretative alternatives (and potential solutions), musical or dramatic, for a stage tradition in flux and reformulation. The libretto by Lucchesi provided a rich scenic apparatus, which accentuated the key themes and situations of the drama, therefore deftly integrating the scenic element into the fabric of the story. Although the opera is grounded in fable, the protagonists are provided with nuanced characterizations, especially the role of Climene. She is a forceful protagonist, whose display and range of emotional depth is compelling. Climene is ultimately; moreover, the catalyst for her reunion with Azem and the redemption of their love through a series of visceral supplications to Cupid. Lucchesi also carefully balances the five soloists with the choral ensemble, which is entrusted at select moments with the narrative and also provided direct interactions with the protagonists in both acts. The poetic verse is generally varied and of a notable quality, although there are moments of clear repetition in the rhyme schemes crafted for the arias. 
This aspect may be a reflection of Lucchesi's status as an amateur librettist. For his part, Millico fulfills the aesthetic declarations of the preface, beginning with the introductory sinfonia that sets the somber mood at the outset of the fable. The orchestra is initially comprised of a modest ensemble of strings, yet it is subtly transformed throughout to include additional accompaniment instruments. As the opera unfolds, Millico expands the resources of the ensemble through a notable inclusion of wind instruments, in particular pairs of oboes, clarinets, flutes, and bassoons as well as the horn. It is in the setting of Lucchesi's verses that Millico is most in sync with Gluck, opting for highly affective accompanied recitatives that predominate in the presentation of the narrative, diverse aria types and the use of choral ensembles often in coordination with the ballet corps. The usage of accompanied recitative takes different forms, especially the accompagnato and obbligato styles and deepens the characterizations of the protagonists. ${ }^{32}$ Millico's inclusion of the rondò, twice in the concluding scene complex of the drama is, as noted earlier, notable as a bold acceptance of concepts posited in Orfeo, but also as a reflection of reform ideology. The melodic content of the arias is often quite notably absent of fioriture, reserved for select moments of impassioned singing. This quality reflects not only Millico's own expressed views, but also those of Planelli, who advocated for a less embellished melodic content to the arias. Indeed, Planelli proclaimed that the arias must be "the most pure, the most simple language of the emotions." ${ }^{33}$ The imprint of reform ideology evident within Millico's score also extends to the frequent appearance of the choral ensemble for critical moments of description, reflection, and action in the drama. ${ }^{34}$ The inclusion of dance to complement the impact of the choral ensembles was undoubtedly to provide a further intensifying of characterization and represented a bold assertion of reform principles. Millico did include in his musical setting, as transparently noted in the preface, concepts often cited by theoreticians and practitioners as counterintuitive to the progressive development of stage drama as a whole. In particular, the score to La pietà does resort to the use of secco-recitative (a concept that Planelli nevertheless continued to endorse enthusiastically), while including the

32 For a brief discussion of the prevailing, contemporary styles of late eighteenth-century orchestral recitative, see McClymonds, "Calzabigi and Paisiello's Elfrida and Elvira," 239-58.

${ }^{33}$ Planelli, Opera in musica, 48. Il più puro, il più semplice linguaggio degli affetti.

${ }^{34}$ The prominent inclusion of choral ensembles within La pietà d'amore undoubtedly presented challenges for Millico in his realization of the opera. Calzabigi had complained bitterly about the lack of choristers in the city for the staging of his own works. See Brizi; also Elena Biggi-Parosi. 
older da capo and dal segno aria types. Millico was certainly not unique in retaining these features, which remained a part of any composer's musical vocabulary at the end of the eighteenth century. The net impact of La pietà d'amore is as compelling statement of reform culture, the incorporation of its aesthetic principles and a demonstration of acceptance into the creative life of Neapolitan theatrical practices.

The aesthetic stances of Millico's declarative preface resonated not only with the ongoing reinvention of the tragic stage throughout Europe, but also it possessed specific elements of continuity to correlative theoretical currents in Naples that extended beyond Planelli's treatise. In forwarding his notions regarding the proper formation of musicians, Millico addresses (whether intentionally or not) the ongoing philosophical dialectic exploring the artistic relationships existing between ancient and modern forms of music. Indeed this theme within the context of theatrical reform establishes connections to the work of one of the most influential and critical minds of late eighteenth-century Naples, who was active at the same time as Millico: Saverio Mattei (1742-95).

Mattei was a scholar of jurisprudence, ancient languages (Hebrew, Greek, and Latin), and natural history, who was educated in Naples and eventually served the administration of the royal Bourbon court in a long and distinguished career. ${ }^{35}$ As a scholar Mattei was prolific, contributing a vast array of publications attentive to contemporary culture and artistic practices with a recurrent theme of his writings the dialectical reconciliation of ancient and modern theater and music. Mattei assiduously posited the notion of parity between the past and present, stating that both had their vices and virtues. He often illustrated his points; moreover, through analyses of Greek and Latin poetic forms to underline their broad ties to contemporary theatrical practices, especially the nature and content of recitative and aria. With his eventual appointment as Arcadian poet and Regio revisore teatrali to the Bourbon court, Mattei occupied a position of critical significance in Neapolitan theatrical practices. It was indeed Mattei, who in the latter position (near the end of his life and career) approved the librettos to be set as operas produced at the Royal Teatro di San Carlo. Mattei was equally concerned as well, whether as a scholar, poet, or administration official, with the decline of contemporary theater,

\footnotetext{
35 Mattei's work is vast and equaled only by scholarship about the scholar. The principal source of his work is Mattei, I libri poetici della Bibbia, 5 vols (Naples: Stamperia Simoniana, 1766-74). For contemporary scholarship, see Fabbri 1993; Fabbri 1998; Di Benedetto 1986; McClymonds 1981.
} 
citing the degradation of the opera libretto, the deprived yet prevailing models of theatrical production (especially the role of the impresario) and the shortcomings of vocal pedagogy (through which he attacked the abuses of the primi divi). Mattei brought together these themes, all central to notions of reform, to decry the loss of the pedagogical and moral responsibilities of theater. It is through these diverse views, interests, and activities that Mattei was drawn into direct contact with and often at the center of discussions focused on theatrical reform in Naples at virtually the same time as Millico and Planelli.

For Mattei the reform of theatrical culture as a whole rested on the return to sacred themes and sources. The reversion to sacred foundations was intended to achieve the social, pedagogical, and ethical functions of Greek tragedy, yet within a Christian framework. This approach set him aside from the reforms of Calzabigi and Gluck, which although it drew on the same, albeit select, legacies of antiquity, was entirely directed toward performance practice and modes of theatrical production. Mattei did value the contributions of these reformers, expressed in his positive, albeit measured assessments of their works and ideologies. ${ }^{36}$ Yet Mattei's orientation toward theatrical reform was not simply artistic, but rather a broader, collective consideration of the place of theater within contemporary Neapolitan society. Mattei summarized these views as, "My intention is not truly to reform theater, but rather to render it more odious by presenting it as it exists, full of defects, and by demonstrating in its entirety the difficulty, indeed the impossibility of reforming it, in order to draw audiences to sacred music." ${ }^{37}$ The intent of this far-reaching conceptualization of theatrical culture was the proposal of a specific, new form of drama, what he described as "tragic sacred theater." ${ }^{38}$ From the perspective of Mattei, this genre could supplant entirely the longstanding and prevailing form of tragedy, which Calzabigi, Millico and others were actively trying to reshape and reform in Naples and elsewhere. Mattei theorized that a tragic

\footnotetext{
${ }^{36}$ Mattei referenced the works of Gluck and Calzabigi in his own writings on theater. Indeed he remarked about Orfeo, that it was "a simple and not too intricate fable, yet still full of emotions." See DiBenedetto, "Music and Enlightenment," 135-153.

${ }^{37}$ As quoted in Fabbri, "Saverio Mattei e la 'musica filosofica," 619: "La mia intenzione non è veramente di riformare il teatro, ma piuttosto di renderlo odioso con dipingerlo qual è, pieno di difetti, e con dimostrarne la difficoltà somma, anzi l'impossibilità di riformarlo, per tirar la gente alla musica sacra."

${ }^{38}$ Mattei made these claims in his critical publication Filosofia della musica (1779). See Fabbri, "Saverio Mattei e la 'musica filosofica," 619-620.
} 
sacred theater offered the possibility of not only resolving the moral and ethical inconsistencies of opera seria, but also the inherent issues of performance (the aforementioned immoderation in the arias) and production practices (especially the star system of divi). To complete his vision of reform, Mattei proposed that this genre, "could be placed into effect by the Sovereign in his own theater restricted specifically for Lent, so that we could enjoy music adapted philosophically to a logical, didactic poetry and in silence hear the sermon of Joash, of Joseph, of Judith, etc. and in this manner one could have Greek music."39

The critical core of Mattei's theatrical purview is evident within these vast prescriptions for the revitalization of contemporary stage practices in Naples. He acknowledges both the need for "reform" of the specific content of tragedy, especially the poetic basis and musical setting (tying him to the broader principles of the reform movement), while reformulating it in a distinctively pedagogical (as well as Neapolitan) context. The latter may be interpreted as a subtle rebuke of the Viennese reforms exemplified by Calzabigi, Gluck, and Millico and assertion of a local, even nationalistic orientation. Yet, Mattei's endorsement of a "tragic sacred theater" does echo, in different terminology, the most subtle elements in the treatise of Planelli and even Millico's declarative preface to La pietà d'amore. It is the further use of theater for formation and the imparting of social and moral values that place him in sync with his contemporaries. The connection to Planelli is even more specific in the endorsement of royal oversight for theatrical production. The theoretician had forcefully advocated in Dell'opera in musica for a theatrical sovrintendente, appointed by the King, who would oversee all elements of production and practices, extending to the content of the works staged at the royal San Carlo Theater. As offered in the previous citation, Mattei also called for the direct intervention of the King himself; however, to realize instead the institution of a "tragic sacred theater" in the royal theater, no less than during Lent; a period that had traditionally banned stage performances in deference to the religious season and its emphasis on prayer, penance, and personal reflection. It is evident; nevertheless, that Mattei's proposals transcended mere theoretical musings given his significant stature within the theatrical culture of Naples and were placed into

\footnotetext{
${ }^{39}$ As quoted in Fabbri, "Saverio Mattei e la 'musica filosofica," 620: "Si potrebbero far eseguire dal Sovrano nel suo particular teatro ristretto specialmente nella Quaresima, acciocchè ci s'andasse a gustar la musica filosoficamente adattata ad una poesia sana, istruttiva, e con silenzio sentir la predica di Gioas, di Giuseppe, di Giuditta, ecc. E così s’avrebbe la musica Greca."
} 
Tradition, Innovation, and Experimentation: The Dramatic Stage and New Modes of Performance in Late Eighteenth-Century Naples

action almost immediately. ${ }^{40}$ The ultimate practical realization of a "tragic sacred theater;" however, was largely the work of the librettist Carlo Sernicola. ${ }^{41}$

Beginning in 1787, the Royal Theater of San Carlo, established a separate and autonomous season of drama dedicated to the production and performance of Lenten tragedy. Sernicola's libretti did not appropriate Mattei's description of "sacro tragico teatro" but rather adopted the phrase azione sacra per musica. ${ }^{42}$ Sernicola's foundational series of libretti, produced between the years 1787-93, form an organic, unified whole that reflect closely the philosophical and aesthetic theories of Mattei. ${ }^{43}$ They are drawn (with the exception of Sofronia ed Olindo) carefully from Old Testament narratives and Sernicola meticulously cites in the libretti the specific passages that serve as the basis for the dramatic representations. The libretti are also accorded a rich scenic apparatus with copious detailed descriptions to serve for the realization of considerable spectacle. The inclusion of stage design is a critical element, setting these works apart clearly from the genre of the oratorio. The dramas are marked; moreover, by a notable emphasis on violence, catastrophe, and a predilection for graphic conclusions. Nevertheless, the analysis of Sernicola's libretti reveals a clear consistency in theme, content (both poetic and musical), and scope to Mattei's conceptualization of "tragic sacred theater." The fact that they were sponsored by the Royal Court dedicated to the sovereigns and performed during Lent are compelling connections to Mattei. They also bear clear correspondences, once again expressed in the works of Mattei, to concepts

\footnotetext{
${ }^{40}$ For a detailed overview of the emergence of Lenten tragedy, see Piperno 1993; Piperno 1991; Mancini 1987; DelDonna 2012, 147-158.

${ }^{41}$ There is scant biographical evidence about Carlo Sernicola. Piperno asserts that he was known in Arcadian circles as "Arimedonte Parmeniate." Regardless, Sernicola was active at the court of Ferdinand IV in the period 1787-95, contributing the formative Lenten dramas, including $\mathrm{La}$ distruzione di Gerusalemme (azione sacra 1787, music by Giuseppe Giordani), Debora e Sisara (azione sacra 1788; music by Pietro Alessandro Guglielmi), Gionata, (azione sacra 1792; music by Nicola [sic] Piccinni), Sofronia ed Olindo (azione tragica 1793; music by Gaetano Andreozzi), and Gli Orazi (azione tragica 1795; music by Nicola Zingarelli). For Sernicola's libretti, see Catalogo dei libretti d'opera in musica dei secoli XVII e XVIII.

42 The term azione sacra per musica has a considerable lineage and had been employed in the early eighteenth century to denote a sacred source, often drawn from the Passion of Christ. The lack of clarity about the phrase led historians to describe these dramas as merely oratorios without consultation of the libretti that present copious scenic design and direction.
}

${ }^{43}$ As noted earlier, La distruzione di Gerusalemme (1787), Debora e Sisara (1788), Gionata, (1792), and Sofronia ed Olindo (1793). 
closely associated with the reform movement and in ideas espoused by Millico and Planelli.

The fourth and final Lenten tragedy by Sernicola was Sofronia ed Olindo set to music by the composer Gaetano Andreozzi (1755-1826) in February 1793 at the Teatro di San Carlo. ${ }^{44}$ This opera represented a noteworthy change in source (and even designation, labeled as azione tragica per musica on the frontispiece) reaching back to Torquato Tasso's epic La Gerusalemme liberata (1581). Sernicola's libretto is derived specifically from Canto II, which recounts the heroic sacrifices of the protagonists under the threat of the Muslim ruler Aladino, his corrupt high priest Ismeno, and their ultimate and unexpected liberation, by the Persian Queen Clorinda. Sernicola hues closely for the most part to Tasso's original poem; however, he does take certain notable liberties. ${ }^{45}$ For example, Sofronia is revealed to be the daughter of Ismeno (a former Christian) and the representation of Aladino is more in line with portrayals of the enlightened, yet despotic ruler of the contemporary operatic stage than his original conception in Gerusalemme liberata. Clorinda, the archetypal warrior-princess, demonstrates a clear empathy from the onset of the action toward Sofronia and Olindo and possesses a clear authority over Aladino, Ismeno and their fellow Muslims. Sernicola's interpretation and telescoping of Tasso's narrative is highly affective, as the drama commences in the aftermath of the disappearance of the icon (or effigy) of the Blessed Virgin Mary as the Christians await their condemnation and death by the Muslims. This initiation of the action post-theft shifts the balance toward the actions and reaction of not only first Sofronia, then Olindo, but also the secondary roles, especially Clotarco in the finale. Sernicola has crafted, in effect, a tightly bound ensemble drama in which each individual member of the cast plays a meaningful role in the eventual resolution of the conflict.

Sernicola's choice of Tasso's epic poem as the basis for the relatively new genre of Lenten tragedy prompts immediate questions about its continuity to the former and also the ongoing cultivation of reform ideals on the opera stage

\footnotetext{
${ }^{44}$ I have consulted the libretto and autograph score in Naples, Carlo Sernicola, Sofronia ed Olindo, azione tragica per musica (Napoli: Vincenzo Flauto, 1793), shelfmark Rari 15.7/2 [note] Olim OE.1.2; Gaetano Andreozzi, Real Teatro di S. Carlo. Anno 1793 | Sofronia ed Olindo | Oratorio Sacro $\mid$ Musica | Del Sig.re D. Gaetano Andreozzi | Parte Prima | Per uso di S. E. Il Sig. re D. Pasquale Caracciolo Marchese di Arena (Napoli, 1793), shelfmark Oratori 5-6.

${ }^{45}$ Sernicola notes in a brief statement in the frontispiece that he has altered select aspects of Tasso's epic. See Sernicola, Sofronia ed Olindo, 5.
} 
in Naples. The change in source is nevertheless consonant to prior works and Mattei's original conception of the genre. There are also clear connections to the revitalization of the tragic genre as espoused by Calzabigi, Millico, and Planelli. Gerusalemme liberata is in essence a medieval romance, yet clearly conceived along the lines of classical antiquity to emulate the epics of Homer and Virgil. The tale recounts the First Crusade in the Holy Land and centers on the notion of Christian triumph, while also placing a premium on the themes of morality, virtue, fidelity, and historical authenticity. All of these ideas are clearly in harmony to Sernicola's prior tragedies, although the latter drew on episodes from the Old Testament. The setting of the drama is nonetheless in Jerusalem within the Semitic East and abounds with exotic elements of temples, ancient religions, sacrifices, and a penchant toward acts of violence in the narrative. Mattei himself was a renowned scholar of classical antiquity and had broadly advocated (as noted earlier) in his works for the reconciliation of these sources within a Christian context, hence the impetus for the autonomous season of Lenten tragedy. There are also clear correspondences to reform ideals in Sernicola's libretto, which then serve as the basis for Andreozzi's impressive music. Sernicola's characters, albeit grounded in Tasso, are vividly realized. They possess a psychological awareness and depth that engenders a fully developed manner of representation. Even in the more violent moments of the narrative, the highly lyrical poetic expressions of faith, love, and fidelity temper these provocative actions, thereby reinforcing a sense of discernment demonstrated by well-defined personages. The strength of the female roles is especially noteworthy. Sofronia and Clorinda are strong, decisive, and ultimately fearless, offering a balance of virtue and strength more often associated with their male counterparts on the stage. ${ }^{46}$ The libretto is also marked by a rich scenic apparatus and Sernicola provides ample notice of direction for the action itself (especially in the large ensemble scenes) and for the individual characters. It is evident that a sense of embodiment was required by the performers, who played the personages of the opera. As noted earlier, the orientation of the libretto is toward the interaction of the ensemble, therefore placing a priority on acting and representation. It is also worthwhile to note that in the year prior to the performance of Sofronia ed Olindo that Calzabigi utilized the medieval historical

\footnotetext{
${ }^{46}$ During the reign of Maria Carolina, there was a notable quantity of dramas that featured compelling female protagonists. For further information, see Mancini 1987; Fabbri 1987; Maione and Seller; DelDonna 2006.
} 
tale of Elfrida for a collaboration with Paisiello at the Teatro di San Carlo. ${ }^{47}$ These characteristics of Sernicola's drama taken altogether establish a robust sense of connection and continuity between the nascent tradition of Lenten tragedy and reform culture.

Andreozzi's setting of the libretto is also infused with concepts and specific techniques associated with reform culture. The composer was among a growing cadre of musicians active in Naples that increasingly exploited the broad instrumental resources of the San Carlo orchestra. Beginning with the single-movement sinfonia that precedes the action, Andreozzi features the expanded wind sections (to include flutes, clarinets, trumpets in pairs) in expressive and prominent roles throughout the course of the drama. The winds are repeatedly engaged as a focal point of the ensemble and form a natural balance to the traditional string core of the eighteenth-century orchestra. This approach to the orchestration undoubtedly accentuates the rich characterizations of the personages in Sernicola's drama. There is also a recalibration of the voice types engaged for those roles. The soprano voice remains foremost (Sofronia, Clorinda, and Ubaldo) as was still customary; however, Andreozzi conceives Aladino and Clotarco as tenors and Ismeno as a bass. ${ }^{48}$ This type of careful calculation once again emphasizes specific characteristics of the individual roles. Although there is an ample retention of traditional secco recitative (which for Planelli remained preferable in tragedy), the critical moments of the narrative, especially in Part II are consistently entrusted to the accompanied form. Andreozzi demonstrates in his score a predilection for the accompagnato and obbligato forms, while also going beyond an exclusive reliance on the string core to include the winds at times in the orchestration of these moments. The most compelling evidence of reform ideals is reserved; however, for the composition of the arias and ensembles.

Throughout the score, Andreozzi conspicuously avoids setting Sernicola's verses in stereotypical aria forms. The diverse types range from the cavatina to binary and ternary structures whose poetic reprises (when included) are written out in full and often through composed as well as distinguished by changes in tempo and meter. There is a sense of building musical and dramatic motion in the solo

\footnotetext{
${ }^{47}$ See DelDonna, Opera, Theatrical Culture, and Society, 73-108.

${ }^{48}$ According to the libretto, the following singers were engaged for the opera: Domenico Mombelli (Aladino); Teresa Macciorletti Blasi (Sofronia), Francesco Roncaglia (Olindo), Giuseppe Trabalza (Ismeno), Maddalena Ammonini (Clorinda), Silvestro Fiamenghi (Ubaldo), and Vincenzo Correggi (Clotarco).
} 
Tradition, Innovation, and Experimentation: The Dramatic Stage and

New Modes of Performance in Late Eighteenth-Century Naples

soliloquies (frequently underlined by the transition from a slow to fast tempo) rather than the hackneyed and illogical da capo or dal segno reprises. The arias are also marked by an almost entire absence of vocal fioriture. The melodic lines are instead taut and declamatory. Andreozzi underlines moments of emotional tension through phrase repetition (generally a single line or couplet of verse) rather than through sectional reprise or melodic embellishment. This approach places an emphasis on expression and embodiment, in other words requiring the vocalist to inhabit fully the personage. Andreozzi's orchestral accompaniment for the arias is equally convincing. The winds are especially involved in roles of support and engagement with the soloist. The arias are a critical part of the tightknit harmonic plan of the entire opera. The central tonality of the opera is E-flat major and characteristically entrusted to Sofronia and Olindo as well as Clorinda at the moment that she orders the protagonists released. Select characteristics of the melodic themes in the arias from both parts of the drama can also be traced back to the sinfonia, (although it is written in the key of D major). The idea of a fully integrated sinfonia was a critical aspect of Gluck's score to Orfeo, while also stalwartly endorsed by Planelli and Millico. Andreozzi also demonstrates fluency with the emergent concept of the scene complex, utilizing this construct at the conclusion of each act, especially the finale to Sofronia ed Olindo.

The scene complex was a relatively recent innovation on the contemporary stage. By design it supported the fluid unfolding of action and in turn allowing more than one musical number without the customary exit of a character. It was inherently conceived to facilitate the joining of several scenes together and the musical content was equally flexible ranging from recitative (all forms) to arias, ensembles, and instrumental interludes. Andreozzi fuses the final four scenes of Sernicola’s libretto (numbers 8-11) to create an extended, yet tightly knit scene complex that brings the protagonists together to effect the conclusion of the opera. The lengthy finale commences with Clorinda's request to Ismeno (in the form of a secco recitative) that she be able to speak with Sofronia and Olindo. Clorinda's subsequent aria (a through composed binary soliloquy) is the vehicle for a growing change of heart toward the Christians in which she openly chastises the bloodlust of Ismeno. Clorinda's transformation in perspective is reinforced by the prevailing key of her aria: E-flat major, the central tonality of the drama and critical pillar for this scene complex (See Table 1.1). The temporary departure of Clorinda (Ismeno remains on stage) gives way to the arrival of Aladino and Olindo. This portion of the scene complex is distinguished by three sections: 1) A lengthy secco recitative 
for the duo during which the Muslim King tries to understand the rationale of his former confidant and soldier Olindo; 2) An accompanied recitative for Aladino (drawing on both obbligato and accompagnato styles), who in the end condemns Olindo (and Sofronia) to death and; 3) A ternary aria for Aladino, marked by evident despair and a reconsideration of the death sentence. Andreozzi distinguishes these sections harmonically, moving from an initial A major (concluding cadence of the secco recitative) to $\mathrm{D}$ major (for the accompanied recitative) and a reprise of $\mathrm{D}$ major for Aladino's aria. This range of tonalities is not simply a notable contrast to the prior E-flat major, but D major is a key closely associated with both Aladino and Ismeno in prior moments of the drama. The careful calibration of the key scheme therefore underlines critical elements in the dramaturgy. As Aladino's aria winds toward close, Sernicola's libretto specifies "A doleful march is heard, followed by a procession of priests and soldiers at the head of which is Ismeno, in order to take Olindo." 49 The meticulous scenic directions present the context for the succeeding section of the complex, namely a gathering of large forces accompanied by the banda (or on-stage chamber ensemble) playing the aforementioned interlude. The march allows Andreozzi the opportunity to reinforce the harmonic architecture of the prolonged ensemble such that it is set in the central key of E-flat major. It also provides the tonality for the succeeding ensemble, involving the entire cast and taking the form of an extended meditation on the lives that hang in the balance. There is an evident musical focus on Sofronia and Olindo in the form of their frequent duet passages with critical interjections offered by the remaining singers, especially Ismeno and Clotarco. The increasing tension is underlined by the acceleration in tempo from Larghetto to Allegro and a concluding quartet. The momentary caesura in the score is succeeded by a reprise of march rhythms to accompany Clorinda's declaration of pardon for Sofronia and Olindo (corresponding to Scene 11 of the libretto). The key is, however, the neutral tonality of $\mathrm{C}$ major, which may suggest that Clorinda no longer considers herself Muslim and yet has not completed the process of conversion that will mark her own death in La Gerusalemme liberata. Nevertheless, this declarative moment gives way to another series solos and a quartet featuring the confrontation and mortal wounding of Ismeno by Clortarco. The reaction to the developments is reflected upon in the next or ninth section of the scene complex featuring primarily the reactions of Aladino (as solo passages) and his exchanges (in the form of paired duets) with Sofronia as Ismeno collapses and dies before acknowledging

\footnotetext{
${ }^{49}$ Carlo Sernicola, Sofronia ed Olindo, 35.
} 
Tradition, Innovation, and Experimentation: The Dramatic Stage and

New Modes of Performance in Late Eighteenth-Century Naples

his parentage of the protagonist (a liberty taken by Sernicola from Tasso's original epic). The underlying harmonic progression is once again a critical element as $\mathrm{G}$ major prevails, therefore neither in Aladino's characteristic D major nor Sofronia's E-flat major. The choice of key offers not a resolution, but rather a momentary suspension of ongoing hostilities. The tenth and final section of the scene complex is a declarative sextet that returns to the central tonality of E-flat major, yet does not present a definitive resolution. The ensemble sings of their ongoing shock and horror at the events that have transpired, instead concluding rhetorically with the question, "When will the heavens ever enjoy peace?" The utilization of the scene complex is a vivid demonstration that by 1793, Andreozzi and his contemporaries in Naples had mastered the critical, initial tenets of reform, yet more significantly extended and built upon them.

The traditional view of Naples and its theatrical culture in the final decades of the eighteenth century has been too often portrayed as conservative and outdated. The present essay establishes how the capital city continued to cultivate a vibrant artistic environment, one in constant dialogue with ongoing change and evolution both within local practices and beyond. The critical resonance of Planelli's treatise Dell'opera in musica is apparent not only in its acceptance of Viennese reform, but also in its keen analysis and assessment of local traditions as well as potential application to Neapolitan theater. The astute findings of Planelli were undoubtedly complimented and in select manners placed into action through the contributions of Saverio Mattei; however, within the philosophical and conceptual outlines of Lenten tragedy. The institution of the azione sacra per musica itself was a convincing testament to the acceptance of change, of progress, and ultimately reform culture given its distinctive realization of Mattei's broad-based theoretical works, which were manifestly consonant to Planelli and even in subtle ways to the work of Calzabigi. The achievements of Giuseppe Millico and Calzabigi in this period must also be considered, who after considerable fame (whether together or individually) returned to Naples, which is a significant testament to the vitality and continued advance of local theatrical traditions. The debt of La pietà d'amore to Orfeo in general and specific ways is unmistakable in the conception of the libretto (especially its declarative preface of aesthetic values) and in Millico's creation of the score. It is ultimately with the realization of Lenten tragedy, exemplified by Sernicola and Andreozzi's Sofronia ed Olindo, that the diverse currents of reform culture can be seen to coalesce. They are brought; moreover, by this new genre of theater to their fullest expression as a thoroughly integrated and original form of 
spectacle that departs emphatically from the convenienze teatrali that flourished for most of the eighteenth century. The gradual, organic development of reform within Neapolitan practices ultimately underlines the continued innovation of theatrical culture in the capital city and its status as one of the most significant musical centers of Europe.

Georgetown University 
Tradition, Innovation, and Experimentation: The Dramatic Stage and New Modes of Performance in Late Eighteenth-Century Naples

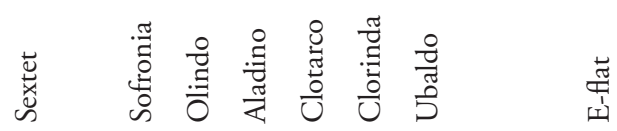

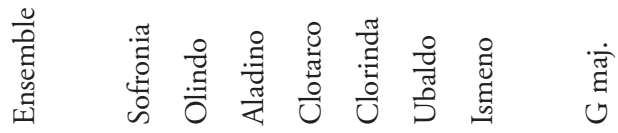

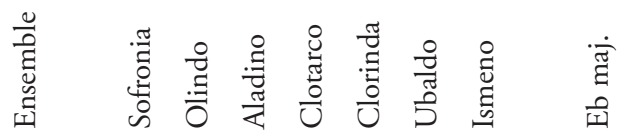

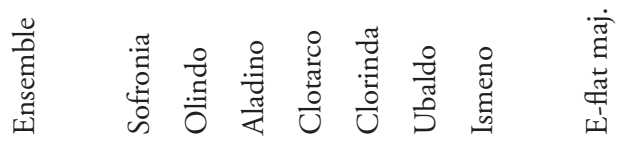

党 党

氶

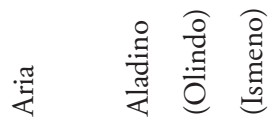

$$
\text { घே }
$$

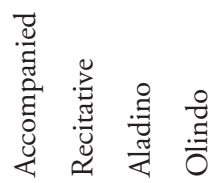

ปี

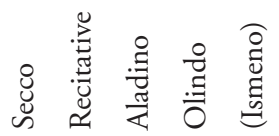

$\frac{\pi}{3} \quad \frac{\pi}{0} \cdot \frac{\pi}{0}$

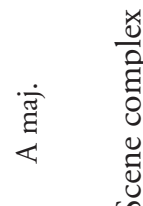

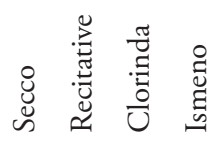

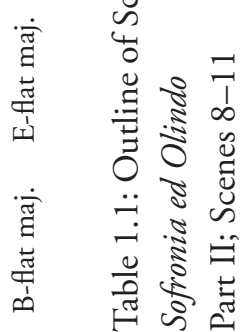



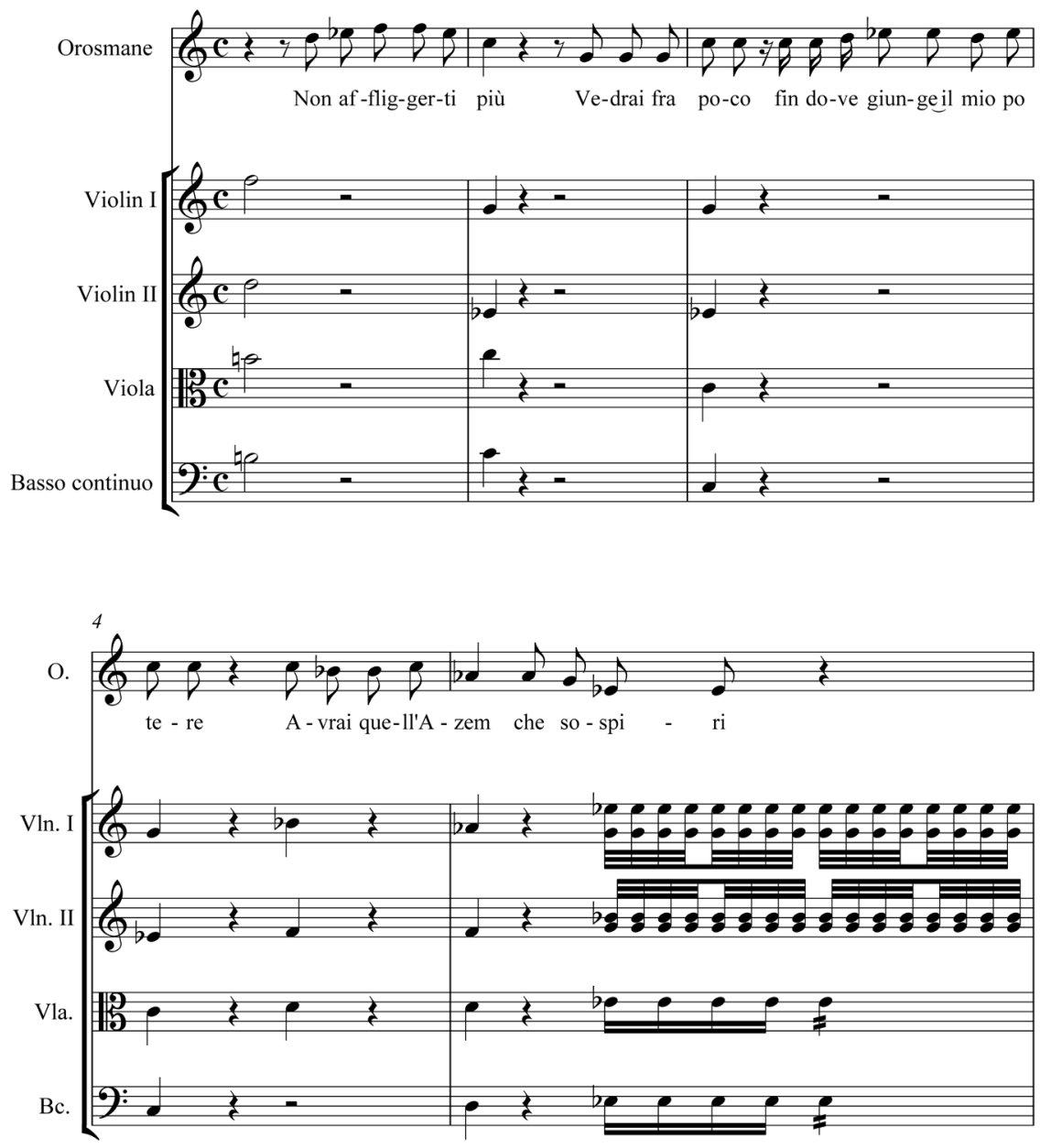
Tradition, Innovation, and Experimentation: The Dramatic Stage and New Modes of Performance in Late Eighteenth-Century Naples
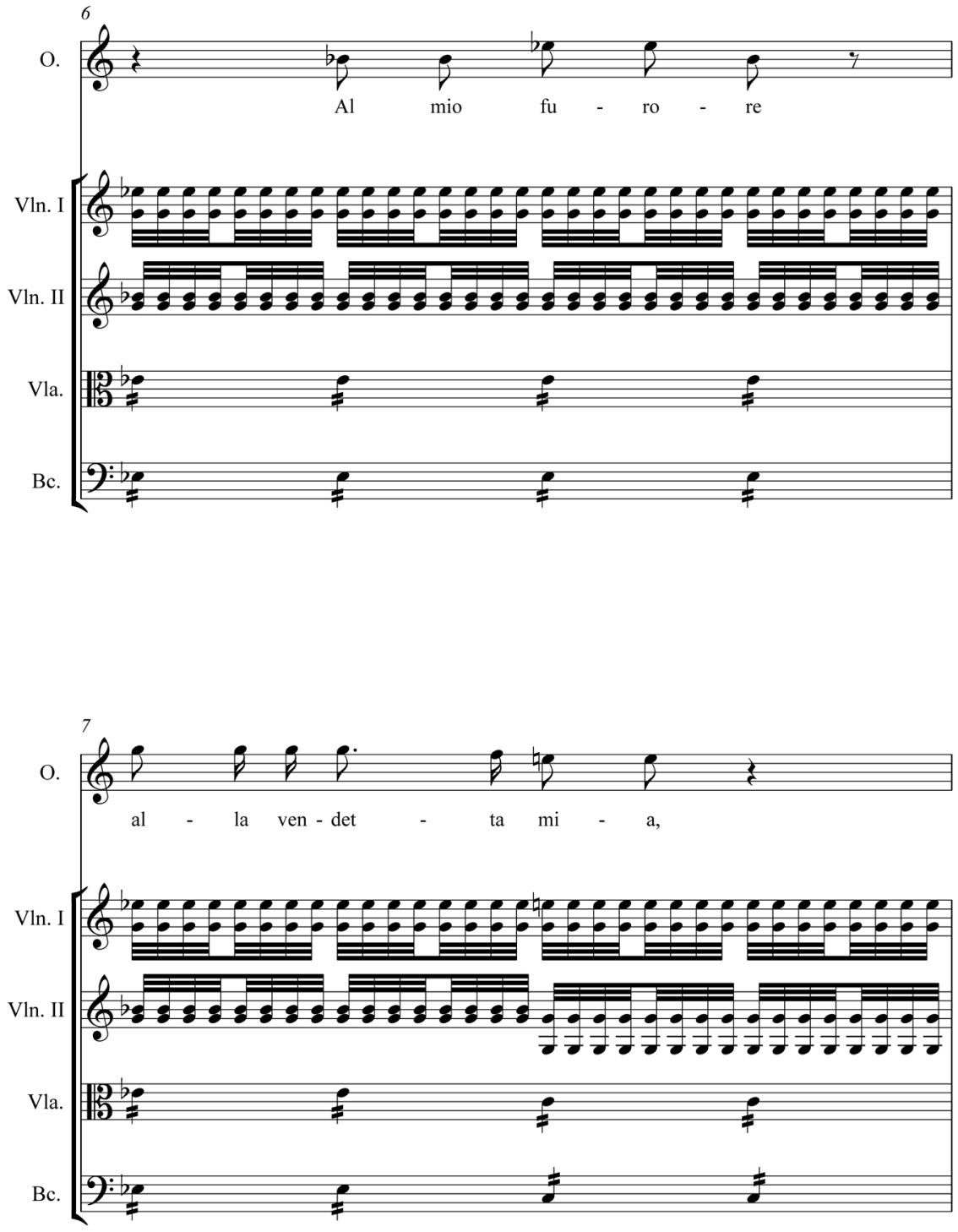

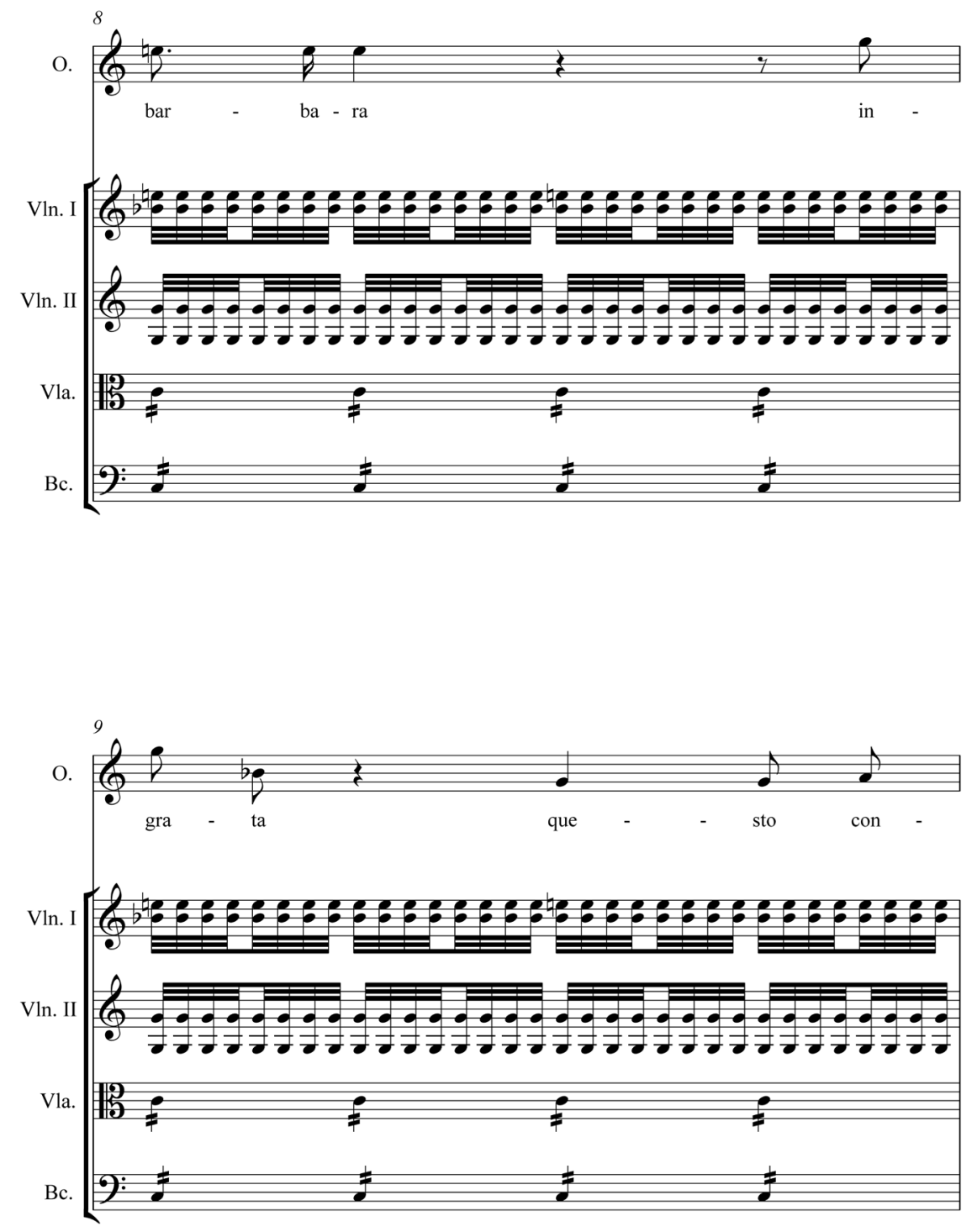
Tradition, Innovation, and Experimentation: The Dramatic Stage and New Modes of Performance in Late Eighteenth-Century Naples
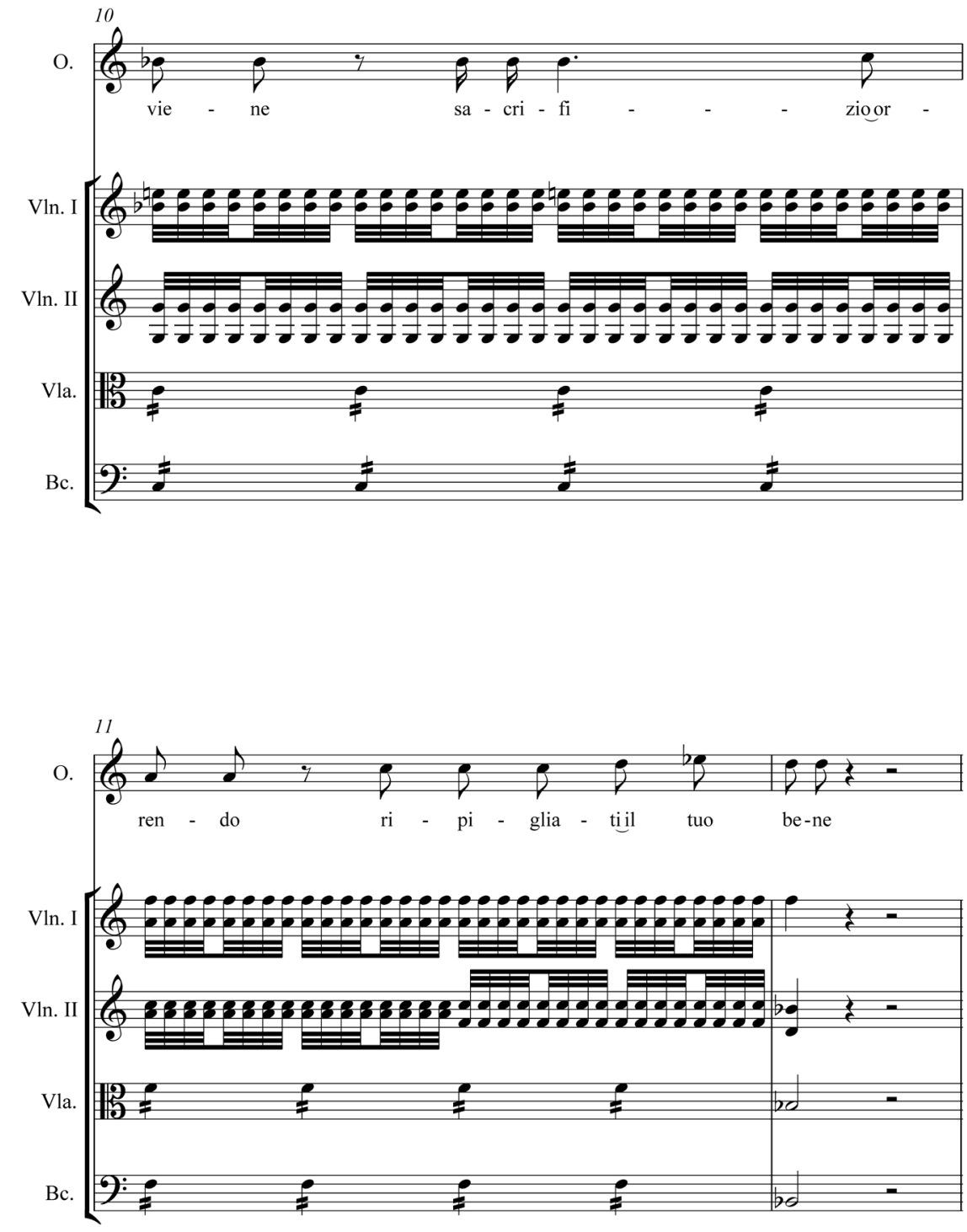


\section{Cited Works}

Andreozzi, Gaetano. Real Teatro di S. Carlo. Anno 1793 | Sofronia ed Olindo | Oratorio Sacro $\mid$ Musica $\mid$ Del Sig.re D. Gaetano Andreozzi | Parte Prima | Per uso di S. E. Il Sig.re D. Pasquale Caracciolo Marchese di Arena. Naples: 1793. Shelfmark Oratori 5-6.

Ball, Philip. The Devil's Doctor: Paracelsus and the World of Renaissance Magic and Science. New York: Farrar, Straus and Giroux, 2006.

Bellina, Anna Laura ed. Ranieri Calzabigi Scritti teatrali e letterati. 2 vols. Rome: Salerno, 1994.

Biggi-Parosi, Elena. "Les Danaïdes di Tschudi-Du Roullet e Salieri e i suoi debiti nei confronti di Ipermestra o le Le Danaidi di Calzabigi" Ranieri Calzabigi tra Vienna e Napoli. Ed. Marri and Russo, 101-127.

Borelli, Rosaria. La Lucchesi Palli: storia di una biblioteca napoletana. Naples: Associazione Voluptuaria, 2010.

Bruno, Brizi. "Uno spunto polemico calzabigiano: Ipermestra e le Danaidi," in $L a$ figura e l'opera di Ranieri de' Calzabigi, ed. Marri, 119-45.

Burney, Charles. The Present State of Music in Germany, the Netherlands, and United Provinces. $2^{\text {nd }}$ Edition. London: T. Becket, J. Robson, and G. Robinson, 1775.

Candiani, Rosy. "Gli anni napoletani di Ranieri de' Calzabigi nelle lettere inedite a Giovanni Fantoni” Studi settecenteschi 32 (1984): 169-96.

Catalogo dei libretti d'opera in musica dei secoli XVII e XVIII. Ed. Francesco Melisi. Salerno: Buonaiuto Sarno, 1985.

Cotticelli, Francesco and Paologiovanni Maione (eds.). Storia della musica e dello spettacolo a Napoli: Il Settecento. 2 vols. Naples: Turchini, 2009.

. Cotticelli, Francesco and Paologiovanni Maione. Onesto divertimento ed allegria dé popoli: Materiali per una storia dello spettacolo a Napoli nel primo Settecento. Milan: Ricordi, 1996.

Croce, Benedetto. I teatri di Napoli. Secolo XV-XVIII. Naples: Pierro, 1891.

Croll, Gerhard and Irene Brandenburg. "Millico, Giuseppe." Grove Music Online. Oxford Music Online. Oxford: Oxford University Press. Accessed February 19, 2015

Degrada, Francesco (ed.). Dell'opera in musica. Fiesole: Discanto, 1981.

Del Donna, Anthony R. Opera, Theatrical Culture and Society in Late EighteenthCentury Naples. Surrey: Ashgate, 2012. 
Tradition, Innovation, and Experimentation: The Dramatic Stage and New Modes of Performance in Late Eighteenth-Century Naples

- "Esotismo e dramma quaresimale nel tardo Settecento a Napoli: Uno sguardo a Debora e Sisara di Sernicola e Guglielmi” Le arti della scena e l'esotismo in età moderna. Ed. Francesco Cotticelli and Paologiovanni Maione. Naples: Turchini, 2006. 421-48.

Di Benedetto, Renato. "Music and Enlightenment" Naples in the EighteenthCentury: The Birth and Death of a Nation State. Ed. Girolamo Imbruglia. Cambridge: Cambridge University Press, 2000. 135-53. "Parole e musica: Il Settecento e l'Ottocento." Teatro, musica, tradizione dei classici. Ed. Alberto Asor Rosa. Turin: Einaudi, 1986. 365-410.

Fabbri, Paolo. "Saverio Mattei: Un profilo bio-bibliografico" Napoli e il teatro musicale in Europa tra Sette e Ottocento: Studi in onore di Friedrich Lippmann. Ed. Bianca Maria Antolini and Wolfgang Witzenmann. Florence: Olschki,1993. $121-44$.

"Saverio Mattei e la 'musica filosofica" Analecta musicologica 302 (1998): 611-29.

"Vita e funzioni di un teatro pubblico e di corte nel Settecento" Il Teatro di San Carlo vol. 2. Naples: Electa, 1987. 61-76.

Finscher, Ludwig. "Der Opernsänger als Komponist: Giuseppe Millico und seine Oper La pietà d'amore." Opernstudien: Anna Amalie Abert zum 65. Geburtstag. Tutzing: Klaus Hortschansky, 1975. 57-90.

Imbruglia, Girolamo (ed.). Naples in the Eighteenth Century: The Birth and Death of a Nation State. Cambridge: Cambridge University Press, 2000.

Lucchesi, Antonio. La pietà d'amore. Cantata a cinque voci. Naples, 1782.

Maffei, M.I. "Alcune osservazioni su Cook o sia gl'Inglesi in Othaiti." Ranieri Calzabigi tra Vienna e Napoli. Marri and Russo (eds.). 209-225.

Maione, Paologiovanni and Francesca Seller. Teatro di San Carlo di Napoli, Cronologia degli spettacoli 1737-1799. Vol. 1. Naples: Altrastampa, 2005.

Mancini, Franco (ed.). Il Teatro di San Carlo. 3 vols. Naples: Electa, 1987 . "Il San Carlo del Medrano 4 novembre 1737 - 13 febbraio 1816." Il Teatro di San Carlo. Vol. 1 Naples: Electa, 1987.

Marri, Federico and Francesco Paolo Russo (eds.). Ranieri Calzabigi tra Vienna e Napoli. Lucca: Libreria Musicale Italiana,1998.

Marri, Federico (ed.). La Figura e l'opera di Ranieri de' Calzabigi. Florence: Olschki, 1989.

Martina, Alessandra. Orfeo-Orphée di Gluck: Storia della trasmissione e della recezione. Turin: Passigli, 1995. 
Mattei, Lorenzo. "La scena napoletana e il contesto europeo: L'opera seria." Cotticelli and Maione 2009, vol. 1.75-112. . I libri poetici della Bibbia. 5 vols. Naples: Stamperia Simoniana, 1766-74.

McClymonds, Marita. "Calzabigi and Paisiello's Elfrida and Elvira: Crumbling Conventions within a Rapidly Changing Genre." Ranieri Calzabigi tra Vienna e Napoli. Marri and Russo (eds.). 239-58. Niccolò Jommelli: The Last Years, 1769-1774. Ann Arbor, MI: UMI Research Press, 1981.

Metastasio, Pietro. Tutte le opere di Pietro Metastasio. Bruno Brunelli (ed.), vol. 5. Milan: Mondadori, 1954.

Millico, Giuseppe. La pietà d'amore. Dramma messo in musica. Naples: GiuseppeMaria Porchelli, 1782.

Piperno, Franco. "Stellati sogli e immagini portentose: Opere bibliche e stagioni quaresimali a Napoli prima del Mosè." Napoli e il teatro musicale in Europa fra Sette e Ottocento: Studi in onore di Friedrich Lippmann. Florence: Olschki, 1993. 267-98.

"Drammi sacri in teatro." Mozart, Padova e la Betulia liberata: Committenza, interpretazione e fortuna delle azioni sacre Metastasiane nel '700. Atti del convegno internazionale di studi 28-30 settembre 1989. Paolo Pinamonti (ed.). Florence: Olschki, 1991. 289-316.

Planelli, Antonio. Dell'opera in musica. Trattato del Cavaliere Antonio Planelli dell'Ordine Gerosolimitano. Naples: Donato Campo,1772.

Robinson, Michael F. Naples and Neapolitan Opera. Oxford: Clarendon Press, 1972. Reprint, New York: Da Capo Press, 1985.

. "The 1774 S. Carlo Version of Gluck's Orfeo" Gluck e la cultura italiana nella Vienna del suo tempo. Atti del convegno (Siena 1973). Chigiana 29-30 n.s. 9-10 (1972-73): 235-592.

Sernicola, Carlo. Sofronia ed Olindo, azione tragica per musica. Naples: Vincenzo Flauto, 1793. Shelfmark Rari 15.7/2 - [note] Olim OE.1.2

Tufano, Lucio. "Musica, ballo e gioco a Napoli nella seconda metà del Settecento: L'Accademia dei Cavalieri e la conversazione degli amici." Spazi e tempi del gioco nel Settecento. Beatrice Alfonzetti and Roberta Turchi (eds.). Rome: Edizioni di Storia e Letteratura, 2011.378-99. I viaggi di Orfeo: Musiche e musicisti intorno a Ranieri Calzabigi. Rome: Edicampus, 2012. 
Tradition, Innovation, and Experimentation: The Dramatic Stage and New Modes of Performance in Late Eighteenth-Century Naples

. "La 'riforma' a Napoli. Materiali per un capitolo di storia della ricezione.” Gluck der Europäer. Kassel: Bärenreiter, 2005. 103-44.

. "Josef Mysliveček e l'esecuzione napoletana dell' Orfeo di Gluck 1774" Hudebni veda 433 (2006): 257-69.

. 'Il poeta 'cadente' e il Re 'filosofo.' Versi ignorati di Ranieri Calzabigi e altri appunti sul suo secondo Settecento soggiorno Napoletano.” Napoli nobilissima 52 (2001): 101-126.

Taruskin, Richard and Piero Weiss. Music in the Western World A History in Documents. $2^{\text {nd }}$ Edition. Belmont, CA: Thomson Schirmer, 2008. 254-255. 
